\title{
The Basis for the Philosophy of Legal Protection for Death Penalty Convicts Who Are Not Executed Immediately After the Verdict Becoming Legally Binding
}

\author{
Abdul Azis Muhammad ${ }^{1}$; Prija Djatmika²; Dhiana Puspitawati ${ }^{2}$; Nurini Aprilianda ${ }^{2}$ \\ ${ }^{1}$ Student at Faculty of Law, Brawijaya University, Malang, East Java, Indonesia \\ ${ }^{2}$ Lecturer at Faculty of Law, Brawijaya University, Malang, East Java, Indonesia \\ http://dx.doi.org/10.18415/ijmmu.v8i12.3237
}

\begin{abstract}
Fundamentally, all forms of punishment are deprivation of human rights. One of the most severe punishments in criminal justice system is death penalty which is specifically aimed at serious crime. Several mechanisms as a form of legal protection for death convicts are judicial review and clemency petitions. Problems arise due to the time difference in the waiting period, which is not limited and in some cases even reaching 20 (twenty) years. Meaning, death penalty convicts have experienced two sufferings at once (double suffering) which is certainly contrary to the principle of punishment in the context of modern criminal law. The research aim is to analyse the basis for the philosophy of legal protection for death penalty convicts who are not executed immediately after the verdict becoming legally binding. This research is a normative legal research with the approach of Law, History, Comparison, Philosophy and Cases. The legal materials used are primary, secondary and tertiary with analytical techniques using perspective analysis. The results of the study indicate that in the future there must be uniformity regarding the waiting time limit regulated in the legislation, namely a period of 10 (ten) years as a form of legal protection for death penalty convicts, so the effectiveness of the death penalty as a preventive and repressive means can be realized.
\end{abstract}

Keywords: Human Rights; Basic Philosophy; Legal Protection; Death Penaltie

\section{Introduction}

The implementation of the death penalty has drawn strong criticism from the community, not only because it does not agree with the death penalty itself but also the implementation of the deferred death penalty which is seen as having suffered the convict during the waiting period for the implementation of the death penalty (Sapardjaja, 2007). Therefore, in the application of the death penalty, facilities are provided in the form of legal remedies in the judicial process that must be passed, such as appeals, cassation, judicial review and clemency. Several countries that still apply the death penalty in their positive laws include Indonesia, China, Iran, Iraq, Pakistan, Sudan and even the United States which is believed to be a supporter of Human Rights and Democracy still maintains the death penalty in 38 of the 50 states in the United States. 
The Indonesian state again executed its citizens some time ago, with the executions of the death row convicts Fabianus Tibo, Dominggus da Silva, and Marinus Riwu on September 21, 2006, for being convicted in the Poso riot case, Sulawesi. Executed more than 2 (two) years after receiving the notification of a court decision that has permanent legal force or about 5 (five) years and 5 months since it was decided by the Palu District Court on April 5, 2001 with a decision no. 459/Pid.B/2000/PN.PL, and the person concerned has filed a judicial review to the Supreme Court and then filed an application for clemency, but was rejected by the President.

Based on this incident, criticism against Indonesia came from various parts of the world and Amnesty International members in various countries (Supandji, 2008). Likewise, the execution of the death penalty for the Bali Bombing I case, Amrozi bin H. Nurhasyim, Ali Ghufron and Imam Samudra with a long waiting period in prison for more than 5 (five) years. Similarly, the case of Sumiarsih who committed premeditated murder in Surabaya against a family with a period of waiting in prison for more than 15 (fifteen) years and finally executed.

The case of Sahar bin Satar, a death penalty convicts in the Riau Prosecutor's Office, has not been executed for several years. In fact, the perpetrator of this premeditated murder was sentenced to death on March 5, 1970. The President as head of state rejected the request for clemency of the convict with Presidential Decree No. 23/G/1972. The convict then applied for a second clemency on April 10, 1979. For almost 25 years since his sentence, Sahar has not been executed.5 This long lapse of time has given the convict legal uncertainty, things like these that must be corrected so that the execution of the death penalty feels fair. for the convicts. Delaying the execution of the death penalty for an undetermined time due to the unclear legal basis regarding the execution time is actually seen as a violation of human rights. The implementation of the death penalty which is postponed without a clear reason and a clear time limit is actually a form of punishment in itself. It is conceivable that the person concerned has already been declared by the court that he will be sentenced to death, all struggles through legal remedies, namely appeals and cassation, reconsideration and clemency have been pursued without success (Sahetapy, 2007).

The issue of the death penalty in Indonesia is related to the formal law that regulates the implementation of the death penalty after the decision has permanent legal force. The waiting period for the execution of the death penalty is quite time-consuming, therefore the existence of the death penalty has become a phenomenon and has been questioned by various groups about its effectiveness and relevance to crime prevention and to the human rights of the convict, because the waiting period for the convict for the execution or execution of the death penalty can reach 25 years. Another example is the execution of Kusni Kasdut and Hengki Tupanwael in 1980 who waited approximately 25 years before being executed. In the case of Liong Wie Tong and Tan Tian Tjoen in Karawang, the execution of the death penalty was only carried out in 2009 after being held in prison for 25 years (Arifin, 2009). The current problem in Indonesia regarding the protracted execution of the death penalty is getting special attention. This happens because there are no rules that determine when to implement or execute the death penalty after a court decision has permanent legal force.

This condition is collided with the right of the convict or his family to file extraordinary legal remedies in the form of a PK (Review) to the Supreme Court and a request for clemency to the President. Although the application for clemency has been limited to only 1 (one) time with the exception of Article 2 paragraph (3) of Law Number 22 of 2002 concerning clemency, there needs to be provisions of laws and regulations governing the maximum time limit for filing extraordinary legal remedies in the form of PK (Review) or clemency by the convict since the notification of a court decision which has permanent legal force is received, thus the convict also obtains legal certainty regarding the execution of the criminal imposed on him. The grace period for the execution of the death penalty against the convict with a judge's decision that imposes the death penalty is from the receipt of notification of a court decision that has permanent legal force and after submitting a judicial review until clemency is rejected by the President. 
Based on the cases described above, it can be seen that the waiting period for convicts before being executed is very diverse, and there seems to be no certainty. Death convicts have indeed committed crimes and caused victims and suffering. However, do not let the state and society retaliate, resulting in excessive suffering (Aryanto, 2011).

In fact, the occurrence of pros and cons regarding the existence of the death penalty is a form of respect for human rights in terms of freedom of opinion. For the state of Indonesia itself, the death penalty is still regulated in its legislation, so this provision must be implemented in the law enforcement process by all law enforcement officers in a professional, proportional and integrity manner by taking into account the values that live in the community even if there are valid reasons. strong enough (juridically) that in its implementation the existence of the death penalty can still be contradicted with the provisions of Law Number 12 of 1995 concerning Corrections, namely fostering behavior towards a better direction.

Discussions and debates among academics, practitioners and observers of human rights protection with reasons and arguments between those who are pro and those who are against the death penalty seem to have never found a common ground, although in recent developments there are not a few experts who initially rejected threats and the implementation of the death penalty, but the authority places more emphasis on imposing the death penalty by judges should be carried out carefully and be the last alternative or death penalty as an ultimum remedium not as a primum remedium, Bambang Poernomo's view at the trial of the Constitutional Court (Abdi, 2007).

The issue of capital punishment is becoming increasingly interesting to be discussed among scientists, so that in the 2009 Dissertation by Zainal Arifin entitled "The Existence of Death Penalty Arrangements and Its Implementation in the Criminal System in Indonesia". The focus of the discussion of the substance of the dissertation is the relation to the existence of the implementation of the death penalty in the criminal law system, while the material for the researcher's dissertation will be discussing "Legal Protection Against Death Convicts Who Are Not Executed Immediately After Permanent Legal Force" of course also related to extraordinary legal efforts, namely Judicial Review and clemency petition to the President. In addition, Suprapto's 2010 dissertation on "Impression of the Death Penalty on Narcotics and Psychotropic Crime Actors in Indonesia in the Perspective of Human Rights Based on the 1945 Constitution". The dissertation discusses the death penalty in relation to narcotics and psychotropic crimes associated with the concept of Human Rights in the 1945 Constitution, both dissertations are from Padjadjaran University, Bandung. The legal protection for death convicts who are not executed immediately after having permanent legal force, is not only related to the convict's right to file extraordinary legal remedies but also to clemency. This is one of the originalities, so the author wants to analyze the basic philosophy of legal protection against death convicts who are not executed immediately after being legally binding.

\section{Research Method}

The type of research used in this study is normative legal research, which is a research in the form of an inventory of the applicable legislation, to seek the principles of the legislation, so this research seeks to make legal findings that are in accordance with a particular case (Diantha, 2016). The research approaches in this study include the statute approach, the case approach, historical approach, comparative approach, and the philosophical approach. The legal materials used are Primary, Secondary, and Tertiary Legal Materials (Soekanto \& Mamudji,2011). The legal materials as referred to in succession consist of: Legislative Provisions (ius contitutum and ius constituendum), international provisions such as the UDHR and the ICCPR; Draft Bill on the 2012 Criminal Code, Draft Bill on the 2015 Criminal Code; and most recently the Draft Bill on the 2019 Criminal Code as the ius constituendum; Indonesian dictionaries, English dictionaries, law dictionaries, encyclopedias and legal journals. 
The collection of legal materials is carried out using internet searches and literature studies (Marzuki, 2010). All legal materials that have been collected and to make it easier to document the archiving of legal materials are adjusted to their respective groupings. A computer or laptop is a device that is used as a tool for data storage and even related data is stored in email as an effort to prevent damage or loss of data. The analysis of the legal material is carried out prescriptive analytically, which aims to produce a prescriptive on what should be the essence of legal research as a legal scientist who is a legal scientist (Setiono, 2004). Guided by the characteristics of legal science as an applied science, the prescriptive provided must be applied as far as possible. 131 The collected legal materials will then be identified by referring to the quality or quality of the data presented.

\section{Results and Discussion}

\subsection{Waiting Period Arrangement in the Context of Death Penalty Execution}

The form of capital punishment is a crime carried out by seizing the soul of someone who violates the provisions of the law. This crime is also the oldest and most controversial crime of various other forms of crime. The purpose of implementing the death penalty is so that the public pays attention to the fact that the government does not want any disturbance to the peace which is very much feared by the public. The execution of the death row convict must be carried out after the court's decision which has been handed down has permanent legal force and the convict has been given the opportunity to apply for clemency to the President. Execution can be carried out by first going through the fiat executie (a statement agreeing to run). A further polemic that has also become a concern is the slow execution of death penalty convictss in Indonesia. The delay in execution is often a public spotlight because it takes years from the convict sentenced to death by the court to the execution process. The following is the arrangement for the waiting period for death executions according to several provisions of the legislation, including;

\section{a. Criminal Procedure Code (KUHAP)}

Extraordinary legal remedies known as cassation in the interests of the law are a factor that is constitutionally justified to delay the execution process. This is a form of caution in imposing the death penalty. Cassation for the sake of law as a filter so that there are no errors in the application of the law that can harm the defendant or convict. Then there is another mechanism (extraordinary legal remedies) that can be proposed, especially by death row convicts against court decisions that have permanent legal force (inkracht van gewjisde). In this case, the application for judicial review (PK) can be submitted to the Supreme Court (Harahap, 2005). In relation to the deadline for submitting the application for judicial review, the Criminal Procedure Code has regulated the following:

Article 264 paragraph (3) of the Criminal Procedure Code, requests for reconsideration are not limited to a period of time. Then Article 268 paragraph (3) of the Criminal Procedure Code, a request for a review of a decision can only be made 1 (one) time. The article above expressly stipulates that a request to submit a request for review is indefinitely. There is no time limit for filing a judicial review with the Supreme Court. In this case, what needs to be considered is whether or not there are supporting reasons for submitting a request for review. However, in subsequent developments, the Constitutional Court has canceled the article above through its decision Number 34/PUU-XI/2013 which limits the submission of a review to only one time which was requested by the former Chairman of the Corruption Eradication Commission (KPK) Antasari Azhar, so the PK can be submitted multiple times. time. Regarding the PK issue that can be submitted multiple times based on the above-mentioned Constitutional Court (MK) decision, the Supreme Court (MA) issued a Supreme Court Circular (SEMA) Number 7. According to the author, this PK issue is indeed more appropriate if the submission must be limited, this means that if the PK proposed by the death row convict is rejected or in other words still 
strengthens the previous decision, it means that the causality is that the convict must be executed immediately.

\section{b. Law No. 14 of 1985 Concerning Supreme Court}

The Constitutional Court in its decision Number 34/PUU-XI/2013 stipulates that a judicial review can be filed multiple times. Thus, the Supreme Court issued a Circular Letter of the Supreme Court (SEMA) Number 7 of 2014 concerning Filing for Judicial Review in Criminal Cases. In point 3 (three) SEMA confirms that PK can only be done 1 (one) time. Theoretically the shift from the perspective of retributive justice to restorative justice in judicial practice can be through the interpretation made by the judge. This aspect is confirmed by the provisions of Article 28 paragraph (1) of Law 14/1970 jo. Law 35/1999 jo. Law 4/2004 stipulates that judges are obliged to explore, follow, and understand the legal values and sense of justice that live in society. While in the provisions of Article 79 of Law 14/1985 jo. Law 5/2004 stipulates that the Supreme Court can further regulate matters needed for the smooth running of the judiciary if there are matters that have not been sufficiently regulated in this law, so that judicial practice carried out by judges does not absolutely refer to legal provisions. positive in accordance with the flow of legism, but also has led and led to the flow of sociological jurisprudence.

\section{c. Law No. 5 of 2010 concerning Amendments to Law Number 22 of 2002 concerning Clemency}

The statutory provisions regarding clemency do not explicitly state the reasons that can be used so that someone can be granted clemency. In the preamble to letters b and c of Law Number 5 of 2010 concerning Amendments to Law Number 22 of 2002 concerning Clemency, it is stated that clemency can be granted by the President to obtain pardons and/or to enforce essential justice and the enforcement of human rights against decisions. court that has obtained permanent legal force, that clemency granted to convicts must reflect justice, protection of human rights, and legal certainty based on Pancasila and the 1945 Constitution. Implicitly the provisions of Article 6A of Law Number 5 of 2010 concerning clemency state the reasons for granting clemency is in the interest of humanity and justice.

Comparison of Law No. 22 of 2002 concerning Clemency with Law No. 5 of 2010 concerning Amendments to Law No. 22 of 2002 concerning Clemency is regarding the limits for submitting applications for clemency, the period for filing clemency, and regarding the authority of the Minister of Law and Human Rights. Law No. 22 of 2002 in Article 2 paragraph (3) states that the application for clemency is not limited to certain conditions, while Law No. 5 of 2010 stipulates that the application for clemency is only one time. The period for applying for clemency according to Law Number 22 of 2002 stipulates that there is no time period for applying for clemency, while Law Number 5 of 2010 stipulates that the period of filing for clemency is limited to one year after the decision has permanent legal force. Then Law No. 22 of 2002 does not regulate the authority of the Minister of Law and Human Rights in the clemency application process, while Law No. 5 of 2010 stipulates a new provision, namely giving authority to the Minister of Law and Human Rights to process clemency applications.

\section{d. Draft Crimina Code (RKUHP)}

Based on academic texts and the Criminal Code Bill, currently the death penalty is still listed as a form of punishment. The death penalty is still maintained but is special and is always threatened with alternatives. So the fundamental change from the provisions of this death penalty is to make the death penalty a special punishment. When compared with the provisions regarding the death penalty in the current Criminal Code, the regulation on the death penalty in the RKHUP is indeed more complete. The RKUHP reorganizes the implementation of the death penalty which is currently regulated in Law Number 2/Pnps/1964 concerning Procedures for Implementing Death Penalty Sentenced by Courts in

The Basis for the Philosophy of Legal Protection for Death Penalty Convicts Who Are Not Executed Immediately After the Verdict Becoming 
General and Military Courts. Even though it is strictly formulated in its implementation, the right to life is a guaranteed right and cannot be reduced under any circumstances, so imposing the death penalty in the Criminal Code Bill would still be against our Constitution. The death penalty in the 2019 Criminal Code Bill is regulated in Article 67 which states that the death penalty is a special principal crime and is always threatened with alternatives.

If the convict during the probationary period shows a commendable attitude and action, then the death penalty can be changed to life imprisonment or a maximum imprisonment of 20 (twenty) years by Presidential Decree. Meanwhile, if the convict during the probationary period does not show commendable attitudes and actions and there is no hope for improvement, then the death penalty can be carried out on the orders of the Attorney General. With this provision, it is possible for the judge to impose a conditional death penalty. So in the provisions of the Criminal Code Bill there is an authority from the President to change the death penalty to life imprisonment as stipulated in Article 101 of the 2019 Criminal Code Bill which states that if the request for clemency of the death convict is rejected by the President and the death penalty is not carried out within a period of 10 (ten) years, it is not because the convict escapes, the death penalty can be changed to life imprisonment by Presidential Decree (Keppres).

\section{e. International Covenant on Civil and Political Rights (ICCPR)}

The imposition of the death penalty raises various controversies. Based on the concept of human rights, the right to life is a non-derogable right. International instruments support the existence of the right to life enshrined in the Universal Declaration of Human Rights and the ICCPR. The death penalty, which is part of the main punishment, is a type of crime that contains pros and cons. At the international level, this type of crime is prohibited from being imposed on the convict. The United Nations (UN) encourages the abolition of the application of this type of crime based on the Universal Declaration of Human Rights adopted on December 10, 1948, by guaranteeing the right to life and protection against torture. Likewise, the guarantee of the right to life is contained in Article 6 of the International Covenant on Civil and Political Rights or ICCPR which was adopted in 1966 and ratified by Law Number 12 of 2005 concerning Ratification of the ICCPR (Anjari, 2015).

Article 4 (2) of the ICCPR stipulates that even in an emergency, even if a country is in a state of emergency, it is not permissible to postpone or reduce certain rights, namely the right not to be tortured, not to be treated cruelly and degradingly, the right not to be enslaved, the right not to be imprisoned simply because of the inability to fulfill a contract, the right not to be sentenced under retroactive law, the right to recognition before the law, and the right to have a belief and religion. The formulation of the 1945 Constitution in this case Article 28I paragraph (1) has the same spirit as the ICCPR. Although there are differences between the 1945 Constitution and the ICCPR (for example, by not stating the right not to be treated or punished in a cruel, inhuman or degrading manner as a right that cannot be reduced under any circumstances), a person's right to life is an equal right. the same is stated in both instruments as non-derogable rights.

\section{f. Convention Against Torture (CAT)}

The Convention against Torture obliges states parties to take effective measures to prevent torture from occurring on their territory and the Convention prohibits the forced return or extradition of a person to another country where he or she is at risk of torture. This convention was adopted by the United Nations General Assembly through Resolution 39/46 on 10 December 1984 and entered into force on 26 June 1987. In honor of this convention, every 26 June is observed as the "International Day in Support of Torture Victims". 
Indonesia itself ratified this convention through Law no. 5 of 1998 on 28 September 1998. Through this law Indonesia also made a declaration against the provisions of Article 20 paragraph (1), paragraph (2) and paragraph (3) and made reservations against the provisions of Article 30 paragraph (1) of this provision. Article 1 paragraph (1) stipulates that torture means any act that is done intentionally, causing great pain or suffering, both physical and spiritual, which is intentionally done to a person to obtain a confession or information from that person or from a third person. or for a reason based on any form of discrimination, if the pain or suffering is inflicted by, at the instigation of, or with the consent of, or with the knowledge of a public official or other person acting in an official capacity.

It is not exempt from pain or suffering arising solely from, attached to, or in addition to legal sanctions. Based on the above understanding, torture can be divided into 3 elements, namely Acts that result in physical or mental suffering; There is "blessing" or silence from the authorized official; and Suffering is the result of a willful act. So it can be divided the level of physical or mental suffering on death row convicts who experience a postponement of execution into two categories, namely postponement of death execution which is included in the category of "torture" and postponement of death execution which is included in the category of "treatment or other cruel, inhuman or demeaning".

\subsection{Analysis of Cases of Death Convicts Who Are Not Executed Immediately}

\section{a. Sumiarsih Case}

The Surabaya District Court on February 20, 1989 sentenced the defendant Sumiarsih to death in the case of the premeditated murder of five members of the family of Lieutenant Colonel Poerwanto. The murder case that occurred on August 13, 1988 did not only involve Sumiasih alone. The following are the defendants who were convicted in this case:

- $\quad$ First Sergeant Adi Saputro, sentenced to death by the Military Court III-12 Surabaya, November 8, 1988 after the presidential clemency attempt was rejected by the President in November 1992, and accepted by the Military Court III-12 Surabaya, November 9, 1992. The convict was executed on December 1, 1992 at 00.15 WIB by firing squad from Kodam V/Brawijaya; Djais Adi Prayitno, was sentenced to death by the Surabaya District Court on January 19, 1989. His request for clemency was rejected by the President through Presidential Decree No. 22 of 1995 dated June 28, 1995, as well as the judicial review that was submitted to the Supreme Court in March 1996. The convict of this death sentence died 21 June 2001 at the Sidoarjo Hospital, East Java before being executed;

- Sumiarsih, was sentenced to death by the Surabaya District Court on January 19, 1989 and executed on July 19, 2008 at around 00.20 WIB by two firing squads of Brimob Polda East Java, Surabaya after several attempts were made, including a request for clemency which was rejected by President Soeharto through Presidential Decree No. 22 of 1995 dated 28 June 1995, then the Supreme Court rejected the judicial review in March 1996, then the second clemency application was rejected by President Megawati in February 2003, and then the subsequent clemency application was also rejected by President SBY through Presidential Decree No. 4G/2008 dated 26 May 2008;

- Sugeng, on January 19, 1989 by the Surabaya District Court sentenced to death, the convict then took legal action for clemency but the request for clemency was rejected by President Soeharto through Presidential Decree No., then the second clemency application was also rejected by President Megawati in February 2003.

- Finally, on July 19, 2008 the convict was executed by two firing squads of the East Java Police Mobile Brigade after waiting for 19 (nineteen) years in prison and was buried in the Sam'an Public 
Cemetery in Malang City next to his mother's grave. The absence of statutory provisions governing the waiting period for death row convicts after the decision has permanent legal force causes the person concerned to feel double suffering. This has caused the paralysis of legal protection for death convicts and has eliminated the constitutional rights of death convicts.

\section{b. Gerson Pandie Case}

The case of Gerson Pandie, Fredrik Soru, and Dance Soru, Indonesian citizens by the Kupang District Court on December 12, 1989, were sentenced to death in the case of the murder of four members of the Pingak family. The President rejected the application for clemency for the three convicts through Presidential Decree No. 27 of 1994. Gerson Pandie and Fredrik Soru had to wait in prison for 12 years before being executed on May 20, 2001 by a special firing squad in Oekabiti, 40 kilometers from Kupang, East Nusa Tenggara. Meanwhile, Dance Soru died in Kupang Class II Penitentiary, in December 2000 due to electrocution. Viewed from the point of view of the purpose of punishment, especially with regard to the combined theory (vereningings theory), then basically only the purpose of retribution (retributivism) is fulfilled. The benefit or prevention side is felt to have not been fulfilled, because basically punishment is oriented to directing a convict to become a better person, even if the person concerned is sentenced to death. Gerson Pandie, et al have been waiting for more than 10 (ten) years in prison and have felt the effect of double suffering, which should have been within the scope of modern criminal law during that period allowing for an evaluation of the personality in question. the opportunity or right of the death penalty convicts to file all available legal remedies.

\subsection{The Problem of Executing Death Convicts Who Are Not Executed Immediately}

\section{a.Juridical Factor}

In Indonesian criminal procedural law, the Criminal Procedure Code is known as the basis for the criminal justice system, becoming the basis in practice, namely as a legal regulation that regulates, organizes and maintains the existence of material criminal law provisions in order to seek and find, and obtain material truth or the real truth. Legal regulations that regulate how and the process of making decisions by judges, and include legal regulations that regulate the implementation stage of judge decisions that have been taken. The Criminal Procedure Code, which was promulgated on December 31, 1981, aims to create legal certainty and rule of law based on truth and justice. The Criminal Procedure Code has determined guarantees for the implementation of the principle of presumption of innocence, regulates legal aid, has provided a legal basis for arrest and detention procedures, and regulates compensation and rehabilitation, it is possible to combine civil and criminal cases in terms of compensation, law, regulates connectivity cases, supervises the implementation of court decisions, and regulates pre-trial proceedings (Kuffal, 2004).

The latest thing, the KUHAP which has lasted for so long turns out to contain many weaknesses, especially in law enforcement by its apparatus, it is necessary to have a series of rational criminal law policies to regulate and rearrange formal criminal law by further strengthening attitudes towards social protection in order to achieve justice in achieve social welfare goals. As a modern procedural law, the weaknesses of the behavior of its apparatus must always be regulated and studied continuously, with approaches from various other social science disciplines. The function and role of the Indonesian criminal justice system is always in the spotlight on various occasions and takes place from time to time, both by criminal law experts and other fields, politicians, practitioners, and even the public contribute their suggestions in order to give appreciation for the criminal justice system in general. consisting of the Police, Prosecutors, Judiciary, Advocates and Correctional Institutions, as determined by law, each running independently in accordance with the limitations of their functions accompanied by responsibilities in carrying out their professionalism. System integration is needed so that there is no

The Basis for the Philosophy of Legal Protection for Death Penalty Convicts Who Are Not Executed Immediately After the Verdict Becoming 
intersection between sub-systems, so that it does not harm the interests of justice seekers of the Indonesian people, even the world community in facing the criminal justice process which until now has become something expensive and can be engineered according to their interests.

\section{b. Socio Factor}

In a sociological perspective, punishment has a certain social meaning because the strength of a sanction depends on the human perception of the sanction/punishment. Durkheim, associated the type of sanction with the type of social solidarity of society. In mechanical solidarity which is based on the equality and total loyalty of individuals, the sanctions applied are repressive. The imposition of sanctions aims to punish crimes or punish acts that violate the social provisions adopted. So that sanctions/punishments can be considered as a tool to satisfy mutual awareness. In a society with organic solidarity based on differentiation between individuals, the sanctions/punishments are restitutive. Therefore, what is needed is an accommodative punishment, its nature is to keep those differences from becoming disintegrative. Apart from people's perceptions of sanctions, humans also have different levels of tolerance for suffering as a result of violations.

Socio-economic position also affects the imposition of the death penalty for a person. As revealed in a study in the United States, it is stated that the death penalty will have a very large effect on poor and minority citizens, when compared to those who come from the white group. This is related to legal assistance for the defendant. They are also more likely to be sentenced to death if they are assisted by a court-appointed lawyer than if they are accompanied by a private lawyer.

The most important factor of the death penalty is the factor of death itself. From the medical aspect, death is indicated by physical death, but the death that may occur is actually not only physical death, but also social death. From a sociological point of view, a person can be called physically alive, but at the same time experiencing social death. This happens when a person is in such a social condition that their freedom to carry out social activities is deprived of them. Social death can be an important alternative in the form of criminal sanctions to replace the death penalty. It is conceivable how someone who is sentenced to life imprisonment twice without the possibility of commutation, he is physically alive but perhaps the suffering he experiences is heavier and longer, especially in terms of social suffering. This convict is isolated from the routine of his social life and this is a very heavy blow, especially having to be separated from his close family for so long.

\section{c. Politic Factor}

The government of President Abdurrahman Wahid had completed 223 decisions for clemency, consisting of 151 decisions to reject and 72 decisions to approve. Then during the reign of Megawati Soekarnoputri, Law Number 22 of 2002 concerning Clemency was passed as the legal basis for the clemency process. President Megawati Soekarnoputri completed 149 clemency decisions, including 116 rejection decisions and 33 approval decisions. The following is a recapitulation of the granting of clemency during the reign of President Megawati Soekarnoputri in the period 2001-2004. During the administration of President Susilo Bambang Yudhoyono, in the period 2004-2010, there were 191 petitions for clemency, which resulted in 62 presidential decrees, of which 51 were rejected and 11 were granted. The clemency decision granted requests from 60 convicts and rejected requests from 131 convicts (State Secretariat Data Source, processed in 2012).

The request for clemency granted by the President can be in the form of changing the form of punishment, reducing the sentence, reducing the duration/number of sentences, eliminating fines and eliminating the remaining sentences. A Presidential Decree regarding clemency (hereinafter abbreviated as Keppres Clemency) may contain one or more applications for the convict. There is no standard and 
standard reference regarding the issuance of a Presidential Decree on clemency, this is usually based on the large number of clemency application files that have been accompanied by considerations from the Supreme Court.66 While a clemency application can consist of one or more convicts depending on the crime committed themselves or together (in alliance). Every request for clemency of the convict will always be accompanied by the consideration of the Supreme Court, as mandated by Article 14 paragraph (1) of the 1945 Constitution of the Republic of Indonesia.

In the period 2004-2010, during the implementation of the granting of clemency there were differences in considerations between the President and the Supreme Court. Of all the Presidential Decrees on Clemency, there are 9 (nine) differences of opinion, including the issuance of Presidential Decree No. 9/G/2006, Presidential Decree No. 6/G/2008, Presidential Decree No. 1/G/2009, Presidential Decree No. 5, 6, 8, 9, 15 and $16 / \mathrm{G} / 2010$. This difference of opinion gave rise to several alternative considerations, namely, the President's considerations rejected but the Supreme Court's considerations were granted, then in the case of the President's considerations were granted while the Supreme Court's considerations were rejected, or the President's considerations were rejected while the Supreme Court's considerations were rejected and accepted. Differences in considerations between the President and the Supreme Court arise in deciding the following decisions:

a) Presidential Decree No. 6/G/2006, which is a request for clemency from a convict who committed a crime of premeditated murder in two different cases. In this case, the Supreme Court considers that there is not enough reason to grant the request for clemency. Meanwhile, the President has the consideration that a person should not be sentenced to prison for more than 20 years, so that the clemency decision is "accepted";

b) Presidential Decree No. 6/G/2008, which is a request for clemency from a convict who commits a criminal act of obscene acts against a child. The Supreme Court has the consideration that the perpetrator of the criminal act is still a minor, and has confessed to his actions, an application for clemency is submitted by his parents, and has served his sentence. Meanwhile, the President considers that the convict's actions have damaged the future of the victim, in this case where the victim is still a minor, the convict commits sexual abuse continuously, and the sentence imposed on the convict is considered commensurate with the act committed, so the clemency decision is "rejected";

c) Decision Number 1/G/2009, which contains clemency requests from 11 (eleven) convicts. The Supreme Court gave two considerations, namely 8 (eight) rejected and 3 (three) accepted. The request that the Supreme Court gave consideration of being granted was a request from a convict who committed a crime to participate in murder. The Supreme Court has the consideration that the convict committed the murder of the victim who is a troublemaker and recidivist who is disturbing the community, another request for clemency is from the convict who committed the crime of murder and without the right to possess, carry, and use sharp weapons. themselves and are still minors (children). However, the President considered that their actions were troubling the citizens and to provide a deterrent effect, so the clemency decision was "rejected".

This shows that the Supreme Court's considerations are quite influential in making a clemency decision by the President. Article 14 paragraph (1) of the 1945 Constitution of the Republic of Indonesia as a legal basis and as a means of checks and balances in the event that the implementation of clemency has functioned properly. Compared to his predecessor, President Susilo Bambang Yudhoyono was recorded as granting the most clemency requests to convicts in narcotics cases. In the era of President Susilo Bambang Yudhoyono, there were 19 clemency (16 Indonesian citizens and 3 (three) foreign nationals, one of which was Shapelle Leigh Corby) and in the era of President Megawati Soekarnoputri, only 1 (one) clemency for Agus Isrok, an Indonesian citizen. and in the era of President Soeharto, there were 7 (seven) clemency for foreign nationals. 
The obstacles faced in solving clemency are generally not technical in nature, but obstacles will arise along with the complexity and problems that accompany the clemency application. Applications for clemency that have problems are generally extraordinary cases related to special crimes, namely narcotics and psychotropic crimes, terrorism crimes and corruption crimes as well as cases involving foreign nationals (WNA) (Tempo Magazine, 2020). In completing the request for clemency, it is not uncommon to have to involve several other agencies for consideration or opinion. For example, involving the Ministry of Law and Human Rights, the Coordinating Ministry for Political, Legal and Security Affairs, the National Narcotics Agency (BNN), Densus 88, the State Intelligence Agency (BIN), the Ministry of Foreign Affairs, and specifically in the case of people sentenced to death, the Attorney General's Office asked for an opinion. Requests for consideration from other institutions will take a long time and may exceed the time limit set by law, that the President in granting clemency decisions within a grace period of 3 months.

In terms of granting clemency to convicts, the President in his function as a head of state is obliged to pay close attention to the considerations or advice given by the Supreme Court. Based on the Decision of the Constitutional Court Number 56/PUU-XIII/2015, in the event that a Presidential Decree (Keppres) is issued in response to a request for clemency submitted by the convict, the president is obliged to pay attention to the provisions of Article 11 paragraph (1) of Law Number 22 of 2002 concerning Clemency which states that the President makes a decision on the request for clemency after taking into account the considerations of the Supreme Court. The Constitutional Court considers that the President in making a decision on a request for clemency submitted by a convict must obtain consideration through a thought process that is carried out carefully, wisely and wisely. In the event that the convict is sentenced to death by the court, the application for clemency is the last resort or the last resort (ultimum remedium) to correct his sentence after taking all available legal remedies. For death row convicts, clemency is a matter of life and death in order to change the verdict. In this case, the death penalty convicts really expects the greatness of a President in his function as head of state.

Clemency and theories in the purpose of sentencing are a unity that cannot be separated. In essence, punishment is a mechanism to change the attitudes and morals of the perpetrators of criminal acts. Clemency appears as a means that can be used for convicts to ask for forgiveness from the President. Today, the objectivity of the President in granting clemency is very much needed by looking at the urgency of granting clemency from theories regarding the purpose of punishment. The President with his privileges (prerogatives) is expected to be wise in considering important aspects to grant or refuse clemency to convicts.

The length of time waiting for the execution of the judge's decision that imposes the death penalty, which has permanent legal force, is a complicated problem faced in both practical and theoretical levels. This is because in the field of criminal procedural law, a decision can only be executed if it has permanent legal force and any legal remedies have been exhausted in order to obtain leniency. In Indonesia, one of the things that must be firmly separated is the process of judicial review and clemency. Reconsideration efforts must be interpreted as a legal process, and clemency must be interpreted as a constitutional (non-legal) effort. This clearly has an impact on the waiting period for the implementation of decisions that impose the death penalty to be different.

The following will describe several cases related to the use of the right to file a judicial review (PK) and clemency requests as follows:

\section{a) Sumiarsih Case}

On Saturday, August 13, 1988, on behalf of the death penalty convicts Sumiarsih, an Indonesian citizen, there was a premeditated murder of five members of the family of Lieutenant Colonel Poerwanto 
in Surabaya.72 In committing the crime, Sumiarsih together with Djais Adi Prajitno and Sugeng, jointly and The allies had intentionally and premeditated to take the lives of 5 (five) victims, namely Marine Lieutenant Colonel Purwanto, Mrs. Purwanto, Haryo Bismoko, Haryo Budi Prasetyo and Sumariyatun.

The beginning of the cause of this murder case was because Sumiarsih was unable to return the loan money obtained from Marine Lieutenant Colonel Purwanto in the amount of Rp. 37,000,000 (thirtyseven million rupiah) at the agreed time limit, namely on August 13, 1988. After the five victims were declared dead, the five were put into Purwanto's Jeep Taft GT, then taken to Songgoriti Malang, then burned and their bodies thrown into the Songgoriti ravine. The Public Prosecutor on January 18, 1989, demanded, among other things, the following: To declare that Defendant I, Mrs. Sumiarsih, Defendant II Djais Adi Prajitno and Defendant III Sugeng, were found guilty of committing a crime as regulated in Article 55 of the Criminal Code jo. Article 340 of the Criminal Code and Article 363 of the Criminal Code paragraphs (1) to 4 and $5 \mathrm{e}$ of the Criminal Code, therefore demanding a sentence against Defendants I and II with the death penalty, while the Defendant III with life imprisonment.

Against the prosecutor's demands, the Surabaya District Court with due observance of Article 340 jo. Article 55 of the Criminal Code and Article 363 of the Criminal Code paragraphs (1) 4th and 5e of the Criminal Code, as well as the articles contained in the Criminal Procedure Code, are stated to be legally and convincingly proven guilty of committing a criminal act intentionally killing two people. or more together; and Theft committed by two or more people jointly by means of damage. Surabaya District Court through its decision No. 80/Pid.B/1988/PN.SBY dated January 19, 1989, sentenced the defendants to the death penalty. Then the person concerned filed an appeal to the Surabaya High Court. The Panel of Judges of the Surabaya High Court through its decision No. 88/Pid/1989/PT.SBY on Tuesday, April 18, 1989 decided to accept the appeal but still upheld the decision of the Surabaya District Court No. 88/Pid/1989/PT.SBY. 80/Pid.B/ 1988/PN.SBY dated February 20, 1989.

Against the decision of the High Court, Sumiarsih et al., filed a Cassation to the Supreme Court. The Panel of Judges of the Supreme Court through its decision No. 1191 K/Pid/1989 on Wednesday 13 September 1989 decided to reject the Cassation application. After the Cassation application was rejected by the Supreme Court, Sumiarsih et al. submitted an application for clemency (first clemency) to the President. The request for clemency from Sumiarsih et al. was rejected by President Soeharto through Presidential Decree No. 22/1995 dated June 28, 1995. Furthermore, against the decision of the Supreme Court of Cassation No. 1191 K/Pid/1989 on the Wednesday, September 13, 1989 mentioned above, Sumiarsih et al. submitted a review to the Supreme Court. The Panel of Judges of the Supreme Court through its decision No. 71 PK/Pid/1995 on Monday, January 29, 1996 decided to reject the application for judicial review from Sumiarsih et al, and determined that the decision requested for judicial review was still valid. Request for Reconsideration rejected.

Furthermore, Sumiarsih et al. submitted a request for clemency (second clemency) to the president. The request for clemency submitted by Sumiarsih et al. was still rejected during the time of President Megawati Soekarnoputri through Presidential Decree No. 21/G/2003 dated February 3, 2003. Then for the umpteenth time Sumiarsih et al. applied for clemency (the third clemency), but the result was still rejected during the presidency of Susilo Bambang Yudhoyono through Presidential Decree No.4/G/2008 dated May 26, 2008, until finally Sumiarsih et al. was executed on July 19, 2008 at 00.20 WIB together with his son Sugeng, by two firing squads (12 personnel), Brimob Polda East Java in East Java Police shooting range, Surabaya.

\section{b) Humprey Ejike Jefferson Case}

Humphrey Ejike Jefferson is a foreign national (Nigerian) sentenced to death for narcotics possession. Starting on Saturday, August 2, 2003 at 17.00 WIB at a restaurant on Jalan Wahid Hasyim 
Tanah Abang, Central Jakarta, the person concerned was arrested by the Narcotics Investigation Unit of the Metro Jaya Police for possession of heroin narcotics stored in a spring bad mattress in his bedroom. The results of the examination of the Criminal Investigations Laboratory of the Criminal Investigation Unit of the Police Lab Number -: 3459/KNF/2003 dated September 19, 2003 concluded that the type of narcotics (Heroin) as meant by the total weight of $1.7 \mathrm{~kg}$ (one point seven kilograms). Humphrey was charged with Article 82 paragraph (1) letter a of Law Number 22 of 1997 concerning Narcotics subsidiary Article 78 paragraph (1) letter b of Law Number 22 of 1997 concerning Narcotics.

The Public Prosecutor on March 9, 2004, demanded, among other things, the following: To declare that the defendant HUMPREY EJIKE or DOCTOR, was found guilty of committing a criminal act of selling, buying, delivering, receiving or being an intermediary in the sale and purchase of narcotics class I as regulated in article 82 paragraph ( 1) letter a of Law no. 22 of 1997 on Narcotics; Sentencing the defendant HUMPREY EJIKE alias DOCTOR, with the death penalty; Determined as evidence in the form of 5 (five) socks each containing Heroin with a net weight of $1.7 \mathrm{~kg}$ (one point seven kilograms). On this claim, the Panel of Judges of the Central Jakarta District Court on April 6, 2004 read out the decision No. 2152/Pid.B/2003/PN.JKT.PST, the order of which is as follows:

1. Stating that the defendant HUMPREY EJIKE or DOCTOR, as stated above has been legally and convincingly proven guilty of committing the criminal act of "Illegally and unlawfully circulating for sale Narcotics Category I";

2. Sentencing the defendant therefore with the death penalty.

Then Humphrey and his legal advisors filed an appeal against the verdict of the first instance. The Panel of Judges of the Jakarta High Court through the decision No. 76/Pid/2004/PT. DKI85 dated June 22, 2004 essentially accepted the appeal request and continued to uphold the decision of the Central Jakarta District Court No. 2152/Pid.B/2003/PN.JKT.PST. Against the appeal decision, Humphrey filed a cassation to the Supreme Court, but on November 4, 2004 the Supreme Court rejected the cassation request through decision no. $1715 \mathrm{~K} / \mathrm{Pid} / 2004$. Humphrey then submitted a request for judicial review on May 16, 2006 requesting that the Supreme Court's decision on the Cassation be reviewed.

The Supreme Court on September 27, 2007 rejected Humphrey Ejike Jefferson's request for judicial review through Decision No. $18 \mathrm{PK} / \mathrm{Pid} / 2007$ and stipulates that the decision requested for judicial review remains in effect, namely the Supreme Court's Decision No. 1715 K/Pid/2004.87. Another effort made by Humphrey Ejike Jefferson was to apply for clemency to President Joko Widodo. However, while in the process of applying for clemency, Humphrey was executed on July 29, 2016 at 00:45 WIB on Nusakambangan Island, Cilacap, Central Java. Whereas explicitly Article 3 jo. Article 13 of Law no. 5 of 2010 concerning Clemency prohibits executions when the death penalty convicts is in the process of applying for clemency. This means that there are maladministration actions carried out by law enforcement officers (AGO) in carrying out the execution of Humphrey Ejike Jefferson because the person concerned has not received any clarity regarding the clemency application being submitted.

\section{Conclusion}

Legal protection for death row convicts who are not executed immediately after becoming legally binding is still based on considerations including:

a. The existence of death convicts who are not executed immediately after being legally enforceable is still an unconstitutional matter in the criminal system, because it is not regulated in the applicable laws and regulations. The existing laws and regulations only regulate several factors 
that can be legally justified to delay the execution of the death penalty, so that it has an impact on criminal law enforcement, namely the failure to achieve the purpose of punishment;

b. The long waiting period for death row convicts who are not executed immediately after becoming legally binding is a matter that is contrary to the principle of legal certainty and the nonfulfillment of legal justice and the benefits of law for the community. Uncertainty in the implementation of the death penalty is certainly contrary to the legal certainty basis of a just criminal law enforcement process. In this case, the death convict is as if he was sentenced to 2 (two) principal penalties at once (double penalty), namely starting with imprisonment first, then the actual punishment imposed on him is in the form of a death penalty. This causes double suffering for the death penalty convictss;

c. The long waiting period for death row convicts who are not executed immediately after being legally enforceable is still a form of action that is contrary to the principles of Human Rights as non-derogable rights.

So that the legislators (Legislatives), it is necessary to make arrangements regarding the waiting period for death penalty convictss in the criminal system. In this case, after regulated various criminal acts that are sentenced to death in material law, then formal law should also regulate everything related to execution issues for death convicts who have permanent legal force, especially regarding the time limit for the execution waiting period and the placement of the convict during the sentence. wait execution.

\section{References}

Abdi, M. (2007). Hukuman Mati (Death Penalty) Terhadap Terpidana Narkotika Pasca Putusan Mahkamah Konstitusi. Jurnal Legislasi Indonesia, 4(4). https://law.uii.ac.id/wpcontent/uploads/2019/10/Laporan-Penelitian-Agustus-2017.pdf

Anjari, W. (2015). Penjatuhan Pidana Mati Di Indonesia Dalam Perspektif Hak Asasi Manusia. E-Journal Widya Yustisia, 1(2): 107-115. https://media.neliti.com/media/publications/247155-penjatuhanpidana-mati-di-indonesia-dala-dc4b10c5.pdf

Arifin, Z. (2009). Eksistensi Pengaturan Pidana Mati Dan Pelaksanaannya Dalam Sistem Pidana Di Indonesia. Bandung, Universitas Padjadjaran.

Aryanto, J. (2011). Legitimasi Hukuman Mati Di Indonesia Dalam Kaitannya Dengan Hak Asasi Manusia. Adil Jurnal Hukum, $\quad$ 2(2): http://lib.law.ugm.ac.id/ojs/index.php/ajh/article/view/1393

Diantha, I M.P. (2016). Metodologi Penelitian Hukum Normatif Dalam Justifikasi Teori Hukum. (Jakarta: Prenada Media Group).

Harahap, M.Y. (2005). Pembahasan Permasalahan dan Penerapan KUHAP: Pemeriksaan Sidang Pengadilan, Banding, Kasasi dan Peninjauan Kembali. II Edition, Fourth Printed. (Jakarta: Sinar Grafika).

Kuffal, H.M.A. (2004). Penerapan KUHAP Dalam Praktek Hukum. (Malang: Universitas Muhammadiyah Malang Press).

Marzuki, P.M. (2010). Penelitian Hukum, (Jakarta: Kencana).

Sahetapy, J.E.(2007). Pidana Mati Dalam Negara Pancasila. (Bandung, Citra Aditya Bakti). 
Sapardjaja, K.E. (2007). Permasalahan Pidana Mati Dewasa Ini Di Indonesia. Jurnal Legislasi Indonesia, 4(4).

Setiono, (2004). Rule Of Law (supremasi hukum). Surakarta, Universitas Sebelas Maret.

Soekanto, S. \& Mamudji, S. (2011). Penelitian Hukum Normatif Suatu Tinjauan Singkat. (Jakarta, Rajawali Pers).

Supandji, H. (2008). Eksistensi Pidana Mati Dalam Proses Penegakan Hukum Di Indonesia. Journal of European Studies, 4(2).

\section{Copyrights}

Copyright for this article is retained by the author(s), with first publication rights granted to the journal.

This is an open-access article distributed under the terms and conditions of the Creative Commons Attribution license (http://creativecommons.org/licenses/by/4.0/). 